\title{
The Approach to Integration of Yimeng Spirit into College Ideological and Political Course
}

\author{
Xianhua Meng \\ Linyi University \\ Linyi, China
}

\begin{abstract}
As an excellent red culture, Yimeng spirit should play its role in the current ideological and political education in colleges and universities, which certainly requires an appropriate approach as an opportunity to integrate the Yimeng spirit into the ideological and political education in colleges and universities. Starting from the connotation and substance of Yimeng spirit, the paper first analyzes the confusion of ideological and political teaching in colleges and universities, and then studies the approach to integration of Yimeng spirit into the ideological and political course in colleges and universities, which provides reference for the application of Yimeng spirit in contemporary ideological and political courses.
\end{abstract}

Keywords-Yimeng spirit; ideological and political course in colleges and universities; education; approach

\section{INTRODUCTION}

As an excellent red culture, Yimeng spirit is a historical summary and a vision for the future; as the spiritual wealth of the Chinese nation, specifically, the Yimeng spirit "is an advanced group consciousness jointly cultivated by the Party, the government, and the people of Shandong, is a lofty spirit of enriching history and reality, tradition and modernity, revolution and construction, reform and opening up, and is a long-lasting ideological treasure", with strong practical guidance.

\section{INTERPRETATION OF THE CONNOTATION AND SUBSTANCE OF YIMENG SPIRIT}

In terms of the specific connotation of the spirit of Yimeng, it can be understood mainly from three aspects, including selfless dedication, hard work, pioneering and advancing, loving the party and loving the army. First of all, for the Yimeng spirit, we must love the party and love the army. The Yimeng people experienced the War of Resistance against Japanese Aggression and the War of Liberation, and under the correct leadership of the Party, the Yimeng people overcame various difficulties and realized their aspirations, so the Yimeng people have lofty political beliefs and formed a firm love of the Party and the army; and at the same time, the spirit of Yimeng has a shining point of loving the party and loving the army, the Yimeng people never take things as they are, they dare to take the road that others have not traveled, so the Yimeng people have the quality of continuous exploration, which reflects the innovation and exploration in the Yimeng spirit and just is the eternal theme of the Yimeng spirit. During the War of Resistance against Japan and the War of Liberation, the Yimeng people always pay more attention to their nation, and facing any danger, they were able to put themselves forward and dedicate themselves, which was completely reflected in the Yimeng spirit. After the founding of the People's Republic of China, the Yimeng people continued to carry forward the revolutionary enthusiasm and struggling spirit in the revolutionary war, and a number of and hardworking pioneers emerged, such as Lijia Zhai, Wangjia Fangqian and Gaojialiu Gou, which were commended by Comrade Mao Zedong personally, which fully showed the self-dependent and hard-working spirit of the Yimeng people, no matter what difficulties they face. The above are all epitome of Yimeng spirit, it represents not only a red culture, but also the spirit inheritance of the old generation of revolutionary martyrs who silently donated all of them for the country, which should deserve our respect and inheritance.

Its advanced nature in theory and spirit is reflected in its progress with the times. The Yimeng spirit experienced the test of years and constantly improved its connotation in the long history, fully reflecting its value and significance. More than that, the Yimeng spirit also enriches the ideological connotation when advancing with the times, furthest in touch with the masses. Therefore, the Yimeng spirit encourages generations of people and points the way for our lives and thoughts.

\section{THE CURRENT CONFUSION IN THE TEACHING OF IDEOLOGICAL AND POLITICAL COURSES IN COLLEGES AND UNIVERSITIES}

The problem of education has gradually emerged with the development of the times. The current ideological and political education in colleges and universities faces enormous challenges, mainly due to the impact of economic globalization, the diversified new topics of social transformation, and the diversified new ideology, the new requirements of information networking and the new changes in the growth of college students, and these all have brought confusion to the ideological and political teaching in colleges and universities. Therefore, it is necessary to find the development direction of ideological and political education in colleges and universities, starting from the current specific challenges.

First of all, it is the impact of economic globalization on the ideological and political education in China's colleges and 
universities. Economic globalization is a double-edged sword, it strengthens the exchanges among countries, connects the whole world as a whole, and accelerates the pace of economic growth, but it also undermines the traditions, ideas and social stability of other countries in the exchange and communication. The most important influence of economic globalization on China's ideological and political education is its influence on the teaching objects in China. China is developing at a high speed and gradually stands on the stage of the world, therefore, the capitalist countries have been carrying out cultural communication and ideological penetration into China, relying on their scientific and technological advantages and economic advantages, which affect the ideological concepts and lifestyle of Chinese people to a certain extent. As the representatives of the advanced thoughts in the times, college students may inadvertently contact the culture of Western countries, including some backward or even decaying cultures, which will impact Chinese cultural construction and cause a negative effect on the construction of spiritual civilization and the dominant position of Marxism in China. As the confluence of ideology and culture, colleges and universities have various ideas gathering, where college students are more or less exposed to different ideas and cultures from different channels, which inevitably causes negative influences and brings troubles for ideological and political teaching in China. The changes of social transformation have also brought certain confusion to the ideological and political education in China's colleges and universities. China is in the critical period of building a well-off society in an all-round way, the social and economic growth mode is gradually transforming, and the social and economic system is gradually reforming; these bring about the diversification of ideology that has impacted China's college education. The main way of influence can be studied from two aspects: the first is the diversification of society from that side, and the second is the change of personal views of ideological and political education objects. These changes affect the guidance of the socialist core value system and have had a negative impact on the ideological and political education in China's colleges and universities.

The new requirements of information network also involve with the ideological and political education of colleges and universities in China. Western countries have more developed science and technology, especially the Internet, which is an important way for them to export their thoughts and culture into China, they have ideological influence on college students in China through various network channels, and have waged a war without smoke in terms of ideology and lifestyle. This kind of network information spreads with a strong capitalism, full of pornography and violence, which has a very bad influence on the recipients of information and endangers recipients' physical and mental health. The times are changing, and the growth of college students has also undergone new changes, which also must be considered in the ideological and political education of colleges and universities in China. The growth change of college students is an opportunity for the ideological and political education in China's colleges and universities, and it is also a challenge in which students need reasonable response and guidance. In the current situation, college students have the following changes compared to the past:
First, psychological pressure is greater. Due to the advancement of society and the increasing employment pressure, college students must acquire more skills to cope with this change, and with the current increase of consumption level, the cost of education for students becomes a burden for some families, therefore, students bear the pressure from society and family and other many aspects.

Second, the emotions are rich and unstable. As an advanced generation of people, contemporary college students have received the advanced ideas and education methods during their growth, therefore, they are more emotional when considering problems and dealing with problems, they like to follow the feelings that lead to a rich emotion, while they have not experienced setbacks in their growth, so they can not make a stable control of their emotional changes.

Third, they have a strong self-awareness. Due to the social environment, most of the college students are the only children in this era, and they are the core in their whole family, therefore, they have a strong self-awareness, like independent thinking and judgment, and can solve problems flexibly and innovatively. However, because of their self-awareness, they often center themselves to habitually persuade others when they accept information, which makes difficulties for ideological and political education. The new changes of college students in their growth must be treated with caution, and as students are the center and focus of education, changes should be planned in the educational methods according to the specific changes of students. The above changes for college students are the characteristics of the times, and only when making corresponding changes according to these characteristics, can we make it more significant of the ideological and political education in colleges.

\section{THE PATH OF INTEGRATING THE YIMENG SPIRIT INTO IDEOLOGICAL AND POLITICAL EDUCATION IN COLLEGES AND UNIVERSITIES}

According to the above analysis, the Yimeng spirit can be used to solve the predicament of ideological and political education in colleges and universities, which is still at the stage of objective theory, so we must get a approach to practical integration of the Yimeng spirit into the ideological and political class of colleges and universities. Such a path must be formulated according to the characteristics of the times and of contemporary college students, and based on the red culture of Yimeng, we must make innovative and reform methods to make excellent culture play its role again and solve the current ideological and political education in colleges and universities, and further achieve such a dual purpose. Based on the literature review and the field investigation, I put forward three suggestions, hoping to provide advice for the integration of Yimeng spirit into the ideological and political education in colleges and universities.

\section{A. Promoting the Red Culture of Yimeng with the Ideological and Political Lessons in Colleges and Universities as Carriers}

The teaching of ideological and political theory courses is the main channel for ideological and political education of 
college students, and the colleges and universities offer this course to cultivate the ideological and moral values of college students and help them establish a correct outlook on life, world outlook and values, thus help to build the socialist core values system for college students to enable them to contribute their strength to socialism, which is an important way to build a harmonious socialist society and a complete well-off society. Based on the core values of socialism that carries a kind of spiritual power, China's socialist core value system includes the party's leadership policy and China's excellent spiritual culture, and the Yimeng spirit is "consistent with the essence and contents of the socialist core value system, with integration of reason and sense, exciting people's mind, and is a vivid manifestation of the core values of socialism and an effective carrier to guide the values of contemporary college students.[3] Therefore, it can realize the combination of Yimeng's red culture and ideological and political courses of colleges and universities to carry forward the red culture of Yimeng with the ideological and political course as the carrier, while it can also enrich the content of ideological and political courses in colleges and universities during the inheritance and promotion of revolutionary culture.

The main reason why current ideological and political education can't attract students is that it has too much highlyabstract theory content, for which students have great difficulties in understanding. The content in lack of material is very unfavorable for ideological and political education, while Yimeng culture has a rich content, of which various historical events and historical figures can increase students' interest in learning, and meanwhile its time and tasks are not beyond our comprehension, with very strong persuasion. Therefore, with colleges and universities as a carrier, Yimeng culture can alleviate the predicament of ideological and political education in colleges and universities.

\section{B. Cultivating the Spirit of College with Yimeng Culture}

The spirit of college is the soul of a university, and it is gradually developed during students and teachers engage in cultural activities. To a certain extent, the spirit of college reflects the cultural accumulation, spiritual beliefs and traditions of the school, which is the ideological education direction of the university. The current colleges and universities are all developing their characteristics and have their spiritual outlook, which is a reflection of the spirit of college to a certain extent.

For example, Linyi University in Shandong Province runs school based on moral education and with the Yimeng spirit as its support, and greatly carries forward the Yimeng spirit: hard work and selfless dedication, bravely marching forward, painstaking efforts, never admitting defeat, developing and forging ahead, daring to win and loving the party and loving the army, which has become a unique style and has achieved remarkable results. Linyi University promotes and carries forward the Yimeng spirit, guides college students to establish firm ideals and beliefs, enhances their patriotism, and carries out various forms of cultural education.

\section{Creating a Campus Culture Environment with Red Culture}

As the existence of ideology, the Yimeng spirit has its subtle influence on students, so colleges and universities can integrate Yimeng culture into the daily life of students through the construction of campus culture, increase the influence of Yimeng spirit, and assist the smooth development of ideological and political education from the indirect sources. In the specific implementation, schools can bring the Yimeng spirit into the classroom, set an elective course of the Yimeng spirit, and also develop campus cultural activities and build a red website, to promote the contact of students with the Yimeng spirit by the above channels, and maximize the influence of Yimeng culture.

\section{CONCLUSION}

Ideological and political education is the key point for colleges and universities, it can help college students establish a correct outlook on life, world outlook and values, thus help college students to build their socialist core values, and make them contribute their strength to socialism, which is an important way to build a harmonious socialist society and build a complete well-off society. The current ideological and political education faces many challenges, but if we integrate it into ideological and political education based on the excellent cultural spirit such as the Yimeng spirit, it can not only alleviate the current predicament, but also carry forward excellent culture. Therefore, we must constantly explore the way to combine excellent culture with ideological and political education, so as to make excellent culture continuously exert its strength.

\section{REFERENCES}

[1] Han Yanming. Research on the Construction of Red Culture and Socialist Core Value System [M]. Beijing: People's Publishing House, 2013.

[2] Xu Dongsheng. Research on Chinese National Spirit [M]. Jinan: Shandong People's Publishing House, 2014.

[3] Xu Dongsheng, Fei Yuhui. Research on Yimeng Spirit [M]. Beijing: Central Party Literature Press, 2014.

[4] Qu Xiao'ou. The History, Current Situation and Countermeasures of the Study of Yimeng Spirit theory[J]. Journal of Linyi University, 2015, (5)

[5] Yuan Pengxin, Tan Suli. The Scientific Connotation and Era Value of Yimeng Spirit[J]. Journal of Linyi University, 2009, (1).

[6] Li Chunhua. Several Issues Concerning Cultural Innovation [J]. Theoretical Exploration, 2011, (3).

[7] An Yingjie. Study on the Yimeng spirit and its value [D]. Northwest Minzu University, 2014.

[8] $\mathrm{Xu}$ Dongsheng. Research on the Education of Socialist Core Values Based on the Education of Yimeng Spirit [M]. Jinan, Shandong people's publishing house. 